\title{
Soil preferences and morphological diversity of goldenrods (Solidago L.) from south-western Poland
}

\author{
Magdalena Szymura1*, Tomasz H. Szymura ${ }^{2}$ \\ ${ }^{1}$ Department of Agroecosystems and Green Areas Management, Wrocław University of Environmental and Life Sciences, pl. Grunwaldzki 24a, 53-363 Wrocław, Poland \\ ${ }^{2}$ Department of Ecology, Biogeochemistry and Environmental Protection, University of Wrocław, Kanonia 6/8, 50-328 Wrocław, Poland
}

\section{Abstract}

Invasive plants in their new range can differ from their ancestors, including traits ultimately influencing habitat preferences, competitiveness and dispersal ability. In Europe Solidago species are considered as one of the worst invaders of American origin. In this study the frequency of occurrence of Solidago species, their soil preferences and morphological diversity, in Silesia (southwestern Poland, Central Europe) were surveyed. On the basis of phytosociological relevés, made using the Braun-Blanquet method, in 75 plots, we determined the composition of species co-occurring with particular Solidago species. The height of ramets, as well as length and width of inflorescences of Solidago species were measured. We also determined the basic soil properties and noted the presence of trees overshading the ground vegetation. The compositional variation of vegetation and its relation to environmental traits: soil properties (texture, $\mathrm{pH}$, percentage of organic matter, total nitrogen, nitrate, phosphorus, potassium and calcium content) and presence of canopy were analyzed by multivariate ordination methods (CA and CCA). Goldenrod species, in most cases (74.3\%) occurred singly, two on one plot - rather rarely (mostly S. canadensis with S. altissima), whereas three Solidago species co-occurred only in three plots. Particular species differed in the height of the plant and inflorescence size, the exception was lack of difference between S. altissima and S. canadensis. S. virgaurea often occurred under trees canopy and the populations were separated from other goldenrod species. The species co-occurring with S. altissima and S. canadensis were the ruderal species, whereas plants from wet meadows occurred in plots with S. gigantea. The distribution of S. graminifolia was very limited, but inside its range it was able to occupy different habitats. The plots, where particular Solidago species occurred, did not differ significantly with respect to soil conditions.

Keywords: plant invasion, Central Europe, soil properties, abandoned fields, life-history traits

\section{Introduction}

Species from genus Solidago are exceptionally successful worldwide invaders from North America [1]. Among about 120 Solidago species three are invaders, which so far have conquered Europe, large parts of Asia, Australia and New Zealand [2].

In central Europe five representatives of the Solidago genus are found. Only one species (S. virgaurea $\mathrm{L}$.) is native, while the other four are of American origin, namely: S. gigantea Aiton, $S$. canadensis L., S. altissima L. [S. canadensis var. scabra (Muhl.) Torr. and Gray] and S. graminifolia (L.) Elliot [3]. Three of the introduced taxa (S. gigantea, S. canadensis and S. altissima) are invasive and morphologically similar to each other. Their

*Corresponding author. Email: magdalena.szymura@up.wroc.pl

Handling Editor: Łukasz Łuczaj

This is an Open Access digital version of the article distributed under the terms of the Creative Commons Attribution 3.0 License (creativecommons.org/licenses/by/3.0/), which permits redistribution, commercial and non-commercial, provided that the article is properly cited. taxonomic status in Europe has been discussed [3-8]. The range of the fourth alien species, S. graminifolia, is small and limited to few locations in Europe [9,10].

The basic chromosome number in Solidago species is $x=9$. $S$. virgaurea and S. graminifolia are diploids $(2 n=18)$. S. canadensis consists of diploid $(2 n=18)$ and tetraploid plants $(2 n=36)$, and S. altissima hexaploid $(2 n=54)$, triploid $(2 n=27)$ and tetraploid $(2 n=36)$ plants of native origin $[11,12]$. While in Europe only diploid plants of these species are noted $[7,13]$, in case of Solidago altissima the occurrence of additional Bchromosomes was observed $[14,15]$. Solidago gigantea occurs in three different cytotypes: diploid $(2 n=18)$, tetraploid $(2 n=36)$ and hexaploid $(2 n=54)$, which represent the whole S. gigantea complex in native range and has also been found in Europe [16]. However, according to current data [17-19] in Europe only tetraploid populations of S. gigantea are known. Therefore, based on this variety in chromosome number, considerable morphological variety in these taxa could be expected [20]. It could also include differentiation in traits related to invasiveness as, e.g. stem height or inflorescence size [21].

Several hypotheses focus on the reasons why alien invasive plants are more successful than other plants in occupying new areas [22-25]. There are numerous confirmations, that plants in the new range could differ from their ancestors, including 
traits ultimately influencing habitat preferences, competitiveness and dispersion ability [26-28]. Additionally, the mechanism of occupancy of particular areas by the given invasive taxa is not clear. It is controlled by two factors: competitiveness or dispersion ability. Moreover, it could be reasonable to think, that the habitat preferences of taxa could lead to non-random occupancy of a wasteland [29-31]. On the other hand the cooccurrence of Solidago taxa on the same patches of vegetation in their native range was observed, where the large aggregation of goldenrods occurs on old fields [32].

In Central Europe many countries underwent socio-economic transformation from socialist to market economy in the 1990s [33,34]. The transformation period resulted in the increase of number of large unproductive areas, mostly abandoned fields. These areas were especially prone to occupation by large stands of goldenrods (Solidago species), as they are currently observed in Europe [35-40].

The aim of this study is to answer several questions related with the problems concerning ecology of invasion of Solidago introduced above. We focused our study on the abandoned fields: which Solidago species occurs there most frequently? Were these taxa able to create single-species stands or the cooccurrence of several species was possible? Do soil properties and the presence of trees control the occupancy of abandoned areas by particular Solidago taxa, as well as influence the lifehistory traits connected with invasiveness (height of plants and size of inflorescences)? Do the habitat ranges of native $S$. virgaurea overlap with alien Solidago species?

\section{Material and methods}

\section{Study area}

Fieldwork took place in Silesia (south-western Poland, Central Europe) between July and September 2008 and 2009. The area of Silesia is ca. $40000 \mathrm{~km}^{2}$.

Seventy-one objects with large stands of goldenrods were chosen for the purpose of study, on the abandoned fields (about
5-10 years with lack of usage, representing Artemisietea vulgaris class, 36 plots) and irregularly mowed meadows (belonging to Molinio-Arrhenatheretea class, 35 plots). Additionally, four objects were located in forests to measure Solidago virgaurea species, which often occurs in forests habitats (Fig. 1). Due to the processes of secondary succession, on some plots (32\%) young trees occurred. The altitude range of the studied plots ranged from 120 to $700 \mathrm{~m}$ a.s.l.

In the study area the average daily temperature is about $8^{\circ} \mathrm{C}$, with annual precipitation of about $580 \mathrm{~mm}$ in the lowland part (130 $\mathrm{m}$ a.s.l.). In the mountains, the temperature decreases to about $6.5^{\circ} \mathrm{C}$, and annual precipitation increases to $1000 \mathrm{~mm}$, at an altitude of $600 \mathrm{~m}$ a.s.l. Most precipitation takes place during the vegetation period.

\section{Study species}

The native species for Europe, $S$. virgaurea, can be easily distinguished from alien Solidago species. Among the invasive species, S. graminifolia is also easily distinguishable from others, on the basis of narrow leaves and flat-topped inflorescences. In America, this species is classified as Euthamia graminifolia on the basis of anatomy and DNA studies [11,12,32]. However, there are discrepancies in taxonomic status of the remaining species, as it was mentioned in the "Introduction". In this paper the species have been distinguished as follows: specimens with hairy stems and leaves are considered as S. canadensis and S. altissima [41,42]. $S$. canadensis has glabrous or sparsely hairy mid to proximal part of stems and leaves narrowly ovate-lanceolate, with abaxial faces glabrous or more commonly hairy along main nerves, adaxial glabrous or slightly scabrous and margins serrate or serrulate (teeth 3-8). Whereas S. altissima has moderately hairy mid to proximal part of stems and leaves oblanceolate, with adaxial faces scabrous, abaxial moderately strigillose, densely villoso-strigillose along nerves and margins finely serrated [teeth 0-6(-14)], distally becoming entire or remotely serrulated. Plants, morphologically similar to $S$. altissima but with glabrous, purplish, covered with wax stems, as well as leaves glabrous both on abaxial and adaxial sides, are considered as S. gigantea $[1,32]$.
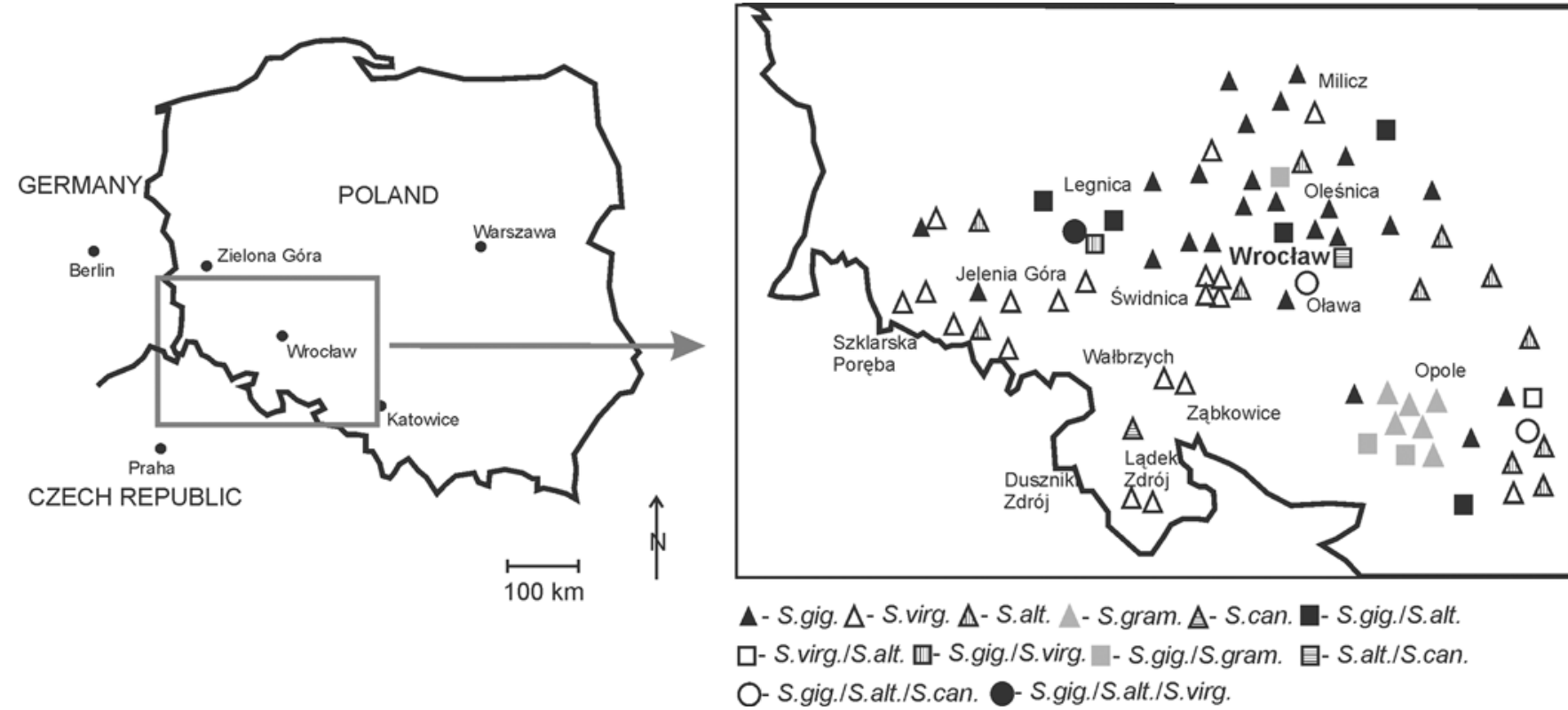

Fig. 1 Location of the study area and the analyzed objects. Abbreviations of species names: S.gig - Solidago gigantea; S.virg. - S. virgaurea; S.alt. - S. altissima; S.gram. - S. graminifolia; S.can. - S. canadensis. 


\section{Field methods}

In each object one $100 \mathrm{~m}^{2}$ square plot was selected; on each of the plots a phytosociological relevé was made according to the Braun-Blanquet method [43]. The nomenclature of plant names was given according to Mirek et al. [44], with the exception of Solidago altissima and S. canadensis, names of which in narrow sense were given according to Rutkowski [42]. All relevés analysed in this paper, with their geographical references and soil properties are stored in the Polish Vegetation Database [45]. When the percentage cover of canopy trees exceeded $10 \%$ we qualified the given plot as overshaded (canopy). Additionally, ten of the largest ramets of each Solidago species in each plot were measured in order to determine the height of plants, as well as the length and width of inflorescences.

The highest plants were selected in order to compare their maximal size at the given site. Bearing in mind the fact, that inside one plot there could be present more than one Solidago species, we measured in total: Solidago gigantea $N=430$ ramets, $S$. virgaurea $N=250, S$. altissima $N=310$, S. graminifolia $N=120, S$. canadensis $N=70$ ramets.

A soil sample from the upper $20 \mathrm{~cm}$ was taken and analyzed for: soil texture, $\mathrm{pH}$, percentage of organic matter (OM) as well as total nitrogen $(\mathrm{N})$, nitrate $\left(\mathrm{NO}_{3}\right)$, phosphorus $(\mathrm{P})$, potassium $(\mathrm{K})$ and calcium $(\mathrm{Ca})$ content. The soil texture was analyzed by the laser diffraction method. The percentage content of sand (particle diameter 1-0.1 mm), silt $(0.1-0.02 \mathrm{~mm}$ ) and clay $(<0.02 \mathrm{~mm})$ was calculated. Percentage of organic carbon was used as a proxy of content of organic matter (OM), the content of $\mathrm{C}$ was determined by the titration method. $\mathrm{N}$ was determined by the Kjehdal method, nitrate was extracted in potassium sulphate and measured in spectrophotometer. $\mathrm{K}$ and $\mathrm{P}$ were extracted from calcium lactate. The content of these elements was then measured in spectrophotometer $(\mathrm{P})$, or flame photometer $(\mathrm{K})$. Ca was extracted from acetic acid and determined in atomic emission spectrophotometer.

\section{Statistical methods}

The compositional variation of vegetation and its relation to environmental traits were analyzed by the multivariate ordination methods: detrended correspondence analysis (DCA) and canonical correspondence analysis (CCA). The significance of environmental variables on species composition was analyzed by forward selection, with $\alpha=0.05$, using Monte Carlo procedures. To reveal the significance of pair-wise relationships between Solidago taxa and environmental variables, the $t$-value biplot method was used [46]. The significance of differences between species, as well as plots in terms of morphological traits and soil properties were checked by the Kruskal-Wallis non-parametric ANOVA, with multiple comparisons of medians as the post hoc test. The significance of differences in plant height and inflorescence size between open plots and those shaded by trees was checked by the Kolmogorov-Smirnov test. The significance of correlations between plant morphology and soil parameters was assessed by Spearman rank correlations.

\section{Results}

Within the investigated objects, the most common species was $S$. gigantea (present in 36 plots), followed by $S$. virgaurea (22), S. altissima (21), S. graminifolia (9) and the rarest, S. canadensis (4 plots). Goldenrods, in most cases (81.4\% of plots) created single-species stands. The occurrence of two species (mostly S. gigantea with S. altissima) in one plot was rare (14.6\% of plots), whereas three Solidago species (S. gigantea, S. altissima and S. canadensis twice, and S. gigantea, S. altissima and $S$. virgaurea once) co-occurred only in three plots (4\%). The number of occurrences of particular Solidago species combinations is shown in Fig. 2.

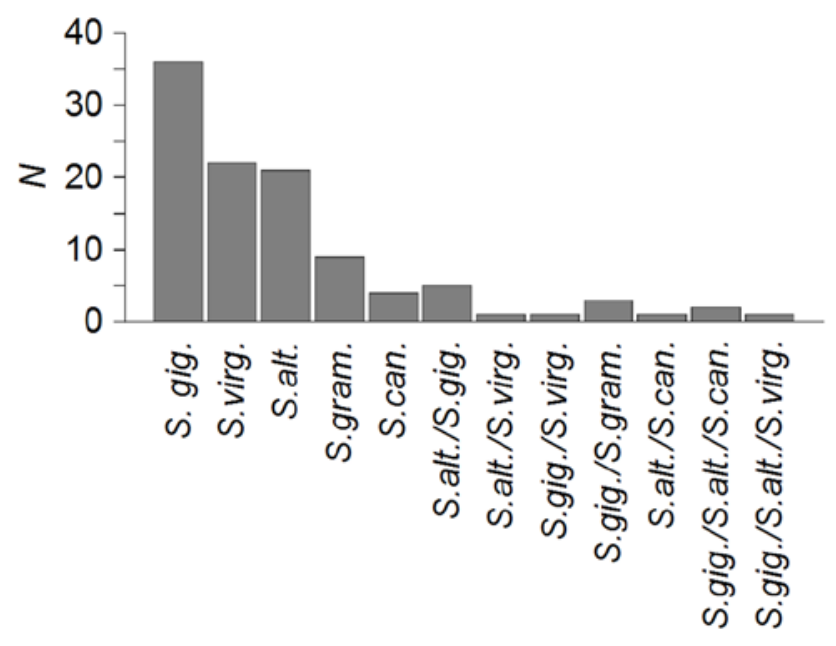

Fig. 2 Number of occurrences of particular combinations of Solidago species in studied objects.

In the investigated stands soils are mostly regosols, with acidic to neutral reaction, low content of calcium, nitrogen, nitrate, phosphorus, potassium, organic matter compared with the average values of the soils of meadows on area of Lower Silesia (Fig. 3, Fig. 4).

The sum of eigenvalues obtained in the ordination analyses (DCA and CCA) was 8.08. The results of the DCA revealed, that four axes explained $20.9 \%$ of the total species variance, including $8.6 \%$ and $4.4 \%$ explained by the first and the second axes, respectively. The ordination (Fig. 5) has clearly distinguished plots with $S$. virgaurea, grouped on the right wing of the diagram together with typical forest and acidophilus species [Vaccinium myrtillus L., Oxalis acetosella L., Maianthemum bifolium (L.) F. W. Schmidt, Anemone nemorosa L. and Hieracium murorum L.], which were different from the alien Solidago species. The second axis seemed to reflect humidity, as could be derived from species composition. S. gigantea was placed closer to species typical for moist habitats (Urtica dioica L., Poa palustris L., Phalaris arundinacea L.). S. altissima and S. canadensis co-occurred mostly with ruderal species [Cirsium arvense (L.) Scop., Tanacetum vulgare L., Artemisia vulgaris L.], whereas $S$. graminifolia was placed close to fresh meadow species (Achillea millefolium L., Ranunculus acris L., Rumex acetosella L., Holcus lanatus L., Festuca rubra L.]. The results of the CCA explained $13.6 \%$ of the variability in species composition, including $7.3 \%$ explained by the first axis and $2.7 \%$ by the second. The first, as well as all ordination axes were significant. The first axis was mostly correlated with altitude, the presence of canopy and OM, while the second was associated with $\mathrm{K}$ and also with the canopy (ordination diagram is not shown). The ordination of species along the first axis again emphasized the difference between plots with native Solidago virgaurea, grouped on the right wing of the ordination diagram and alien Solidago species, generally placed in the center of plot. However, no environmental variables were significantly related to particular Solidago taxa, with the exception of $S$. virgaurea related to altitude. 

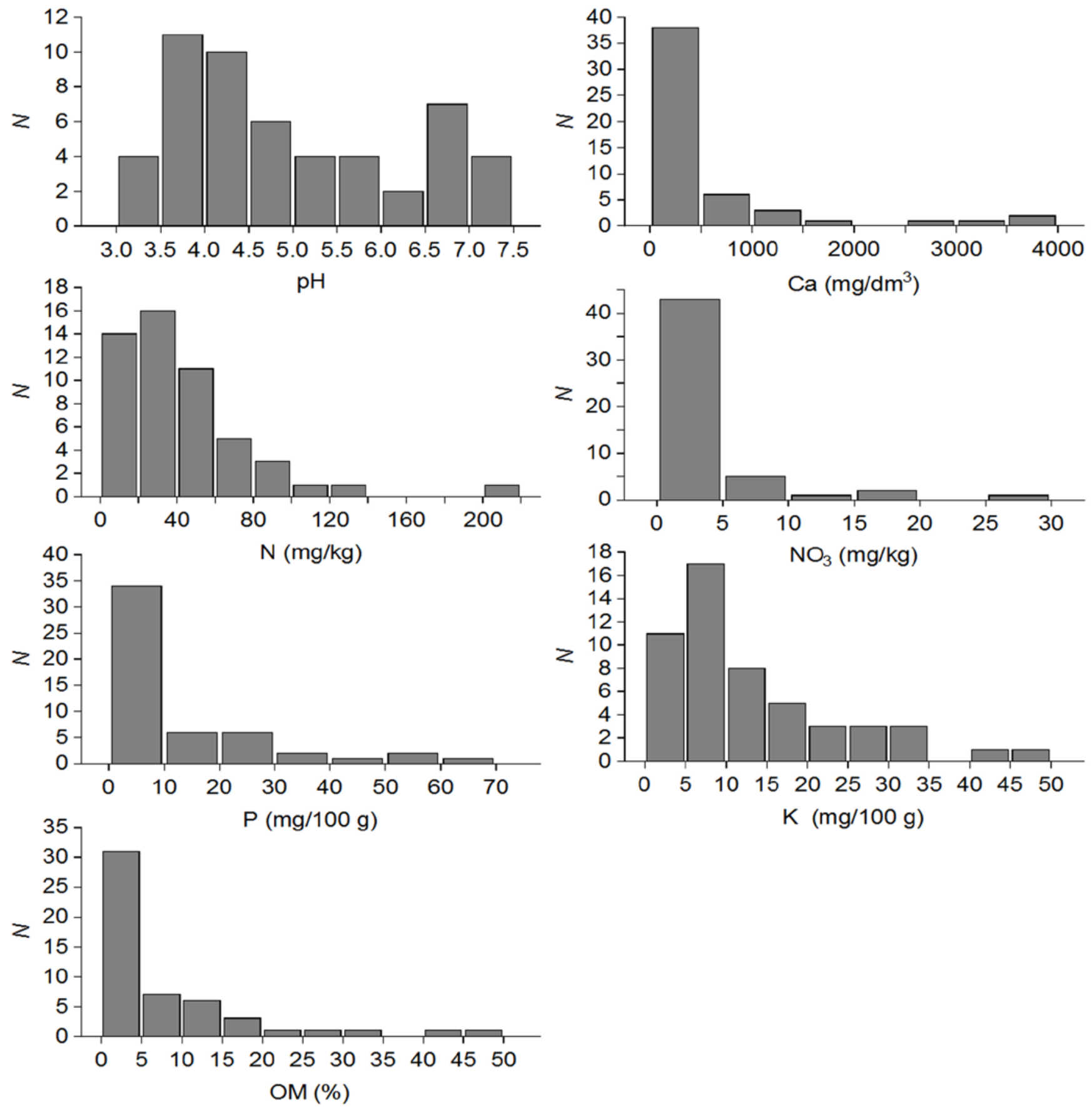

Fig. 3 The distribution of the measured chemical soil parameters. The vertical axes present the number of plots $(N)$. The horizontal axes present: $\mathrm{pH}$ value, content of calcium $(\mathrm{Ca})$ nitrogen $(\mathrm{N})$, nitrate $\left(\mathrm{NO}_{3}\right)$, phosphorus $(\mathrm{P})$, potassium $(\mathrm{K})$ and organic matter $(\mathrm{OM})$.
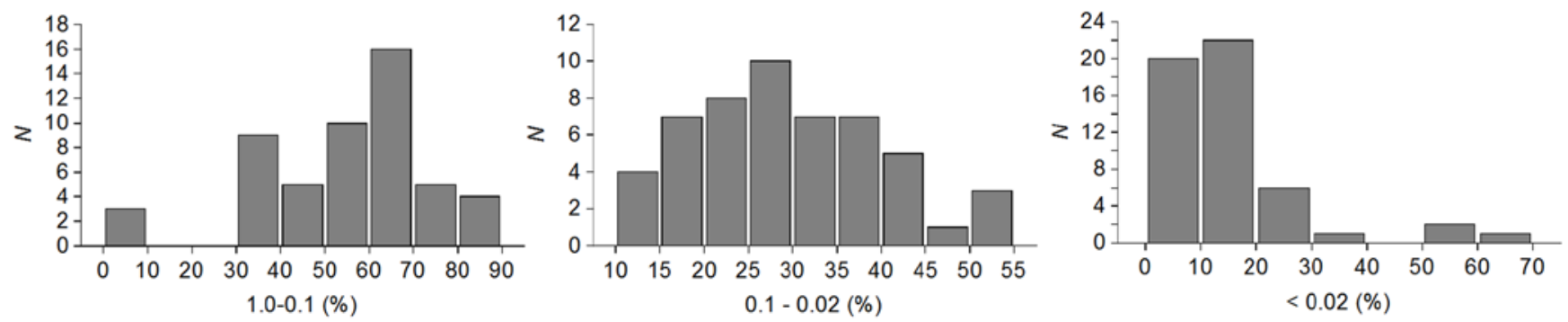

Fig. 4 The distribution of different classes of soil texture. The vertical axes present the number of plots $(N)$. The horizontal axes present: percentage of particles with size of 1.0-0.1 (sand), 0.1-0.02 (silt), $<0.02$ (clay). 


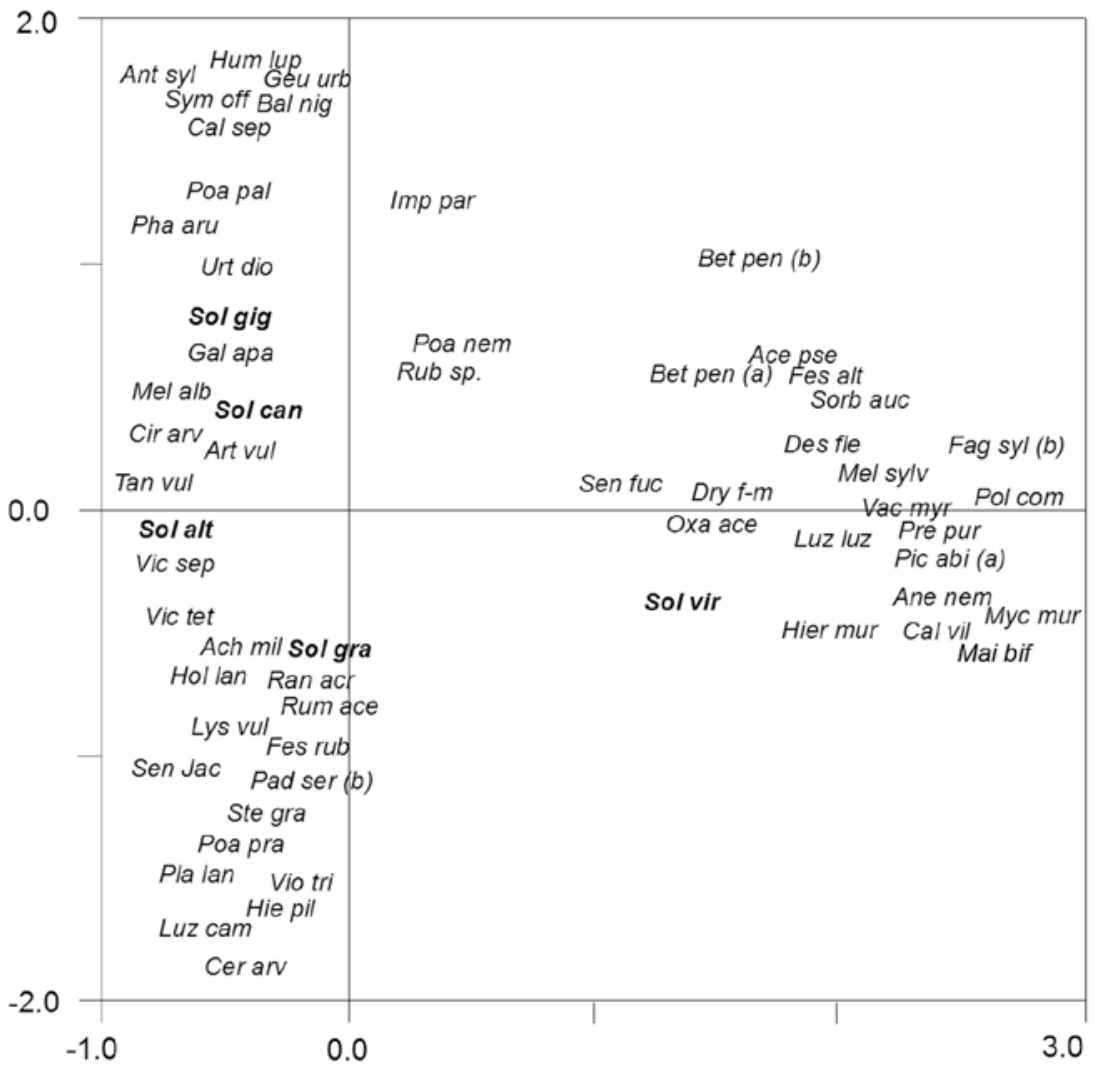

Fig. 5 The species ordination plot of the DCA. The small letters in parentheses indicate the layer of vegetation: $a-$ tree layer, $b$ - scrub layer; species from herb layer are not assigned. Only species with a species fit value above $10 \%$ are shown. The abbreviations of the species names are based on the first three letters of the genus and species name [a list of full names of the included species: Acer platanoides L., Acer pseudoplatanus L., Achillea millefolium L., Anemone nemorosa L., Anthriscus sylvestris (L.) Hoffm., Artemisia vulgaris L., Ballota nigra L., Betula pendula Roth, Calamagrostis villosa (Chaix) J. F. Gmel., Calystegia sepium (L.) R. Br., Campanula patula L., Cerastium arvense L., Cirsium arvense (L.) Scop., Deschampsia flexuosa (L.) Trin., Dryopteris filix-mas (L.) Schott, Echium vulgare L., Elymus repens (L.) Gould, Equisetum arvense L., Euonymus europaea L., Fagus sylvatica L., Festuca altissima All., Festuca arundinacea Schreb., Festuca ovina L., Festuca rubra L., Filipendula ulmaria (L.) Maxim., Fragaria vesca L., Galium aparine L., Geranium pratense L., Geum urbanum L., Hieracium murorum L., Hieracium pilosella L., Holcus lanatus L., Humulus lupulus L., Impatiens parviflora DC., Knautia arvensis (L.) J. M. Coult., Lotus corniculatus L., Luzula camprestis (L.) DC., Luzula luzuloides (Lam.) Dandy \& Wilmott, Lycopus europaeus L., Lysimachia vulgaris L., Maianthemum bifolium (L.) F. W. Schmidt, Medicago lupulina L., Medicago sativa L., Melampyrum sylvaticum L., Melandrium album (Mill.) Garcke, Mentha arvensis L., Mycelis muralis (L.) Dumort., Myosotis arvensis (L.) Hill, Oxalis acetosella L., Padus serotina (Ehrh.) Borkh., Phalaris arundinacea L., Phleum pratense L., Picea abies (L.) H. Karst., Plantago lanceolata L., Poa nemoralis L., Poa palustris L., Poa pratensis L., Populus tremula L., Potentilla reptans L., Prenantes purpurea L., Ranunculus acris L., Rubus sp., Rumex acetosella L., Sedum acre L., Senecio ovatus (P. Gaertn., B. Mey. \& Scherb.) Willd., Senecio jacobaea L., Solidago altissima L., Solidago canadensis L., Solidago gigantea Aiton, Solidago graminifolia (L.) Elliott, Solidago virgaurea L., Sorbus aucuparia L. emend. Hedl., Stellaria graminea L., Symphytum officinale L., Tanacetum vulgare L., Tragopogon pratensis L., Urtica dioica L., Vaccinium myrtillus L., Veronica officinalis L., Vicia sepium L., Vicia tetrasperma (L.) Schreb., Viola arvensis Murray, Viola tricolor L.].

In subsequent analysis the plots, where Solidago virgaurea was the only Solidago species were excluded. Thus we obtained a subset of data, where plots with alien Solidago species were compared, and $S$. virgaurea occurred as an admixture. The CCA explained $12.9 \%$ of the variance. The first axis explained $5 \%$, the second $3.1 \%$ and the third $2.6 \%$ of the species variance; both the first, as well as all canonical axes were statistically significant. As it is presented in Fig. 6, the environmental variable could explain the general variability in species composition: the first axis was correlated with altitude, the second with $\mathrm{OM}$ and canopy, and the third with P. However, none of the environmental variables were associated with a particular alien Solidago species. Additionally, it should be emphasized that $S$. graminifolia was placed exactly between other alien Solidago species in the ordination (Fig. 6). The distribution of S. graminifolia is very limited, but inside this range it is able to occupy different habitats.
Particular species differed in the height of the ramets and inflorescence size, but the exception was lack of difference between S. altissima and S. canadensis (Fig. 7). These two species were the tallest and their inflorescences were the biggest. $S$. gigantea had medium height and size of inflorescence. Within the two shortest taxa, S. graminifolia was more uniform - the height of ramets and the size of inflorescences were similar in the all investigated plots. $S$. virgaurea represents the biggest variety of the investigated traits.

The environmental traits affect Solidago morphology. We found positive correlations between the height of S. gigantea and $\mathrm{OM}$ and $\mathrm{NO}_{3}$ and $\mathrm{S}$. altissima and $\mathrm{Ca}$ and $\mathrm{K}$, as well as between inflorescence length of S. gigantea and $\mathrm{NO}_{3}$, S. altissima and $\mathrm{pH}$ and K, S. graminifolia and OM. The inflorescence width of $S$. altissima was correlated with $\mathrm{Ca}, \mathrm{pH}$ and $\mathrm{K}$. Additionally, the height and inflorescence length of $S$. virgaurea decreased with altitude (detailed results of the tests not shown). 


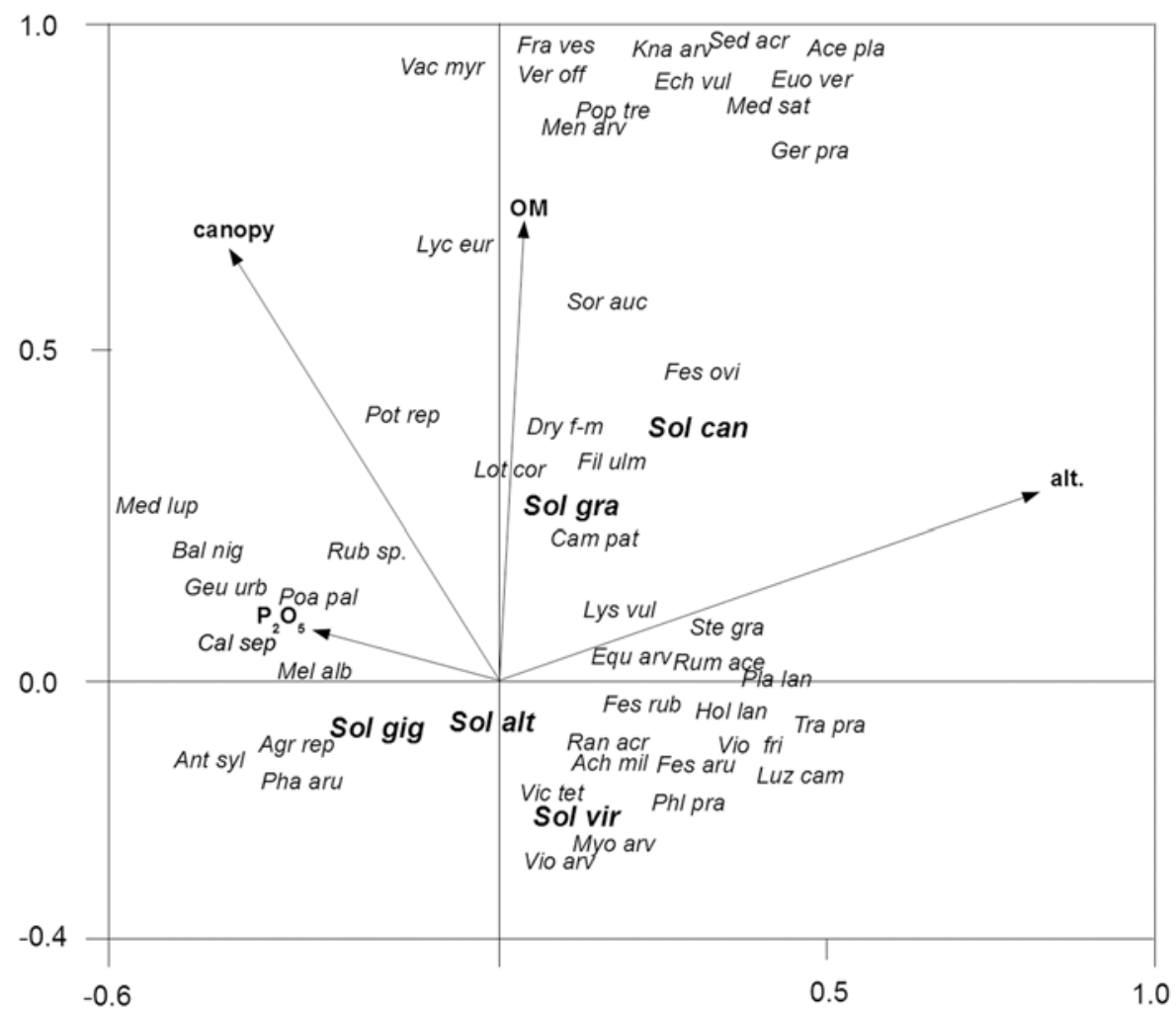

Fig. 6 The species-environmental variable biplot of CCA plots (the plots where S. virgaurea was the only Solidago species were excluded). The abbreviations of the species names are based on the first three letters of the genus and species name (for a list of full names of the included species see Fig. 5). Only species with a species fit value above $10 \%$ were shown, all species visible on graph belong to herb layer. The significant environmental variables are shown as black arrows.

Ramets of S. virgaurea, growing under canopy trees, were shorter (the average height on open plots was $89.9 \mathrm{~cm}$ while under canopies $60.7 \mathrm{~cm}, P=0.025$ ) and produced smaller inflorescences compared to those in open sites (the average length of inflorescences on open plots was $39.0 \mathrm{~cm}$, but under the canopy $22.1 \mathrm{~cm}, P=0.01)$. The inflorescence size of $S$. gigantea under the canopy was also smaller, compared to those on open sites (the average length of inflorescences on open sites was $23.7 \mathrm{~cm}$, whereas under the canopy this was $18.9 \mathrm{~cm}, P=0.042$ ). The measured traits of another species did not differ significantly between plants growing under canopy and open areas.

\section{Discussion}

It is known, that Solidago species: S. altissima, S. canadensis, S. gigantea and S. graminifolia often co-occur in old fields within their native range [32]. The results of our study show, that in most cases in the invasive range, goldenrods create single species stands. We think, that species which reach the new suitable habitats as first, create a dense stand, which does not allow for the establishment of another species. It could be assumed, that it is an effect of strong expansiveness due to the lack of natural enemies in the new range because natural pests were not transported from native range. Moreover, at a new range no local insects feed on goldenrods. The field observations from western part of Central Europe confirm, that introduced plants of Solidago gigantea are larger and create denser stands than in their native range [47]. The authors [47] explain it by the evolution of increased competitive ability hypothesis [48], namely there is a trade-off between investment into defense against herbivores and pathogens, and investment into stronger competitive ability.

The separation of the species cannot be explained by soil texture, $\mathrm{pH}$ or nutrient content. Such a lack of differentiation has been observed in other parts of Europe [8,49,50]. Several studies from America have also confirmed a lack of differences with respect to these soil parameters between Solidago taxa, which are invaders in Europe [51,52], particularly S. altissima and $S$. gigantea. However, when the small-scale distribution was considered, populations of Solidago gigantea tended to attain their greatest abundances on moist soils, while those of S. altissima tended to be more dense on intermediate-moisturelevel soils [32]. Additionally, S. graminifolia achieved its highest abundance on acidic soils [32]. On the other hand, results of this study show, that differences in the height of ramets and inflorescence size can be related to soil parameters and overshading by trees.

Plant height and inflorescence size, as morphological traits are directly connected with competitiveness and reproduction, and considered to be useful in assessing invasive potential of the species [53-55]. The results of our study show, that different Solidago species revealed different potential invasiveness expressed by morphological traits. The large inflorescences, placed high above the ground, should theoretically result in a stronger reproductive effect [56-58] in case of plants with wind-dispersed seeds. However, in our study, the most widely distributed species, S. gigantea, had a medium inflorescence size and ramet height. In case of these species, where the ratio of the mass of inflorescences to the whole plant mass was higher than 


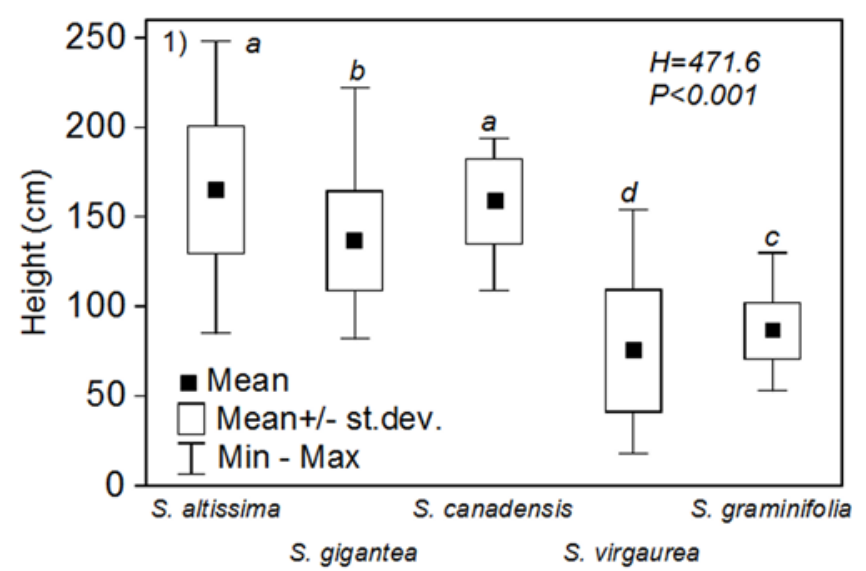

Species
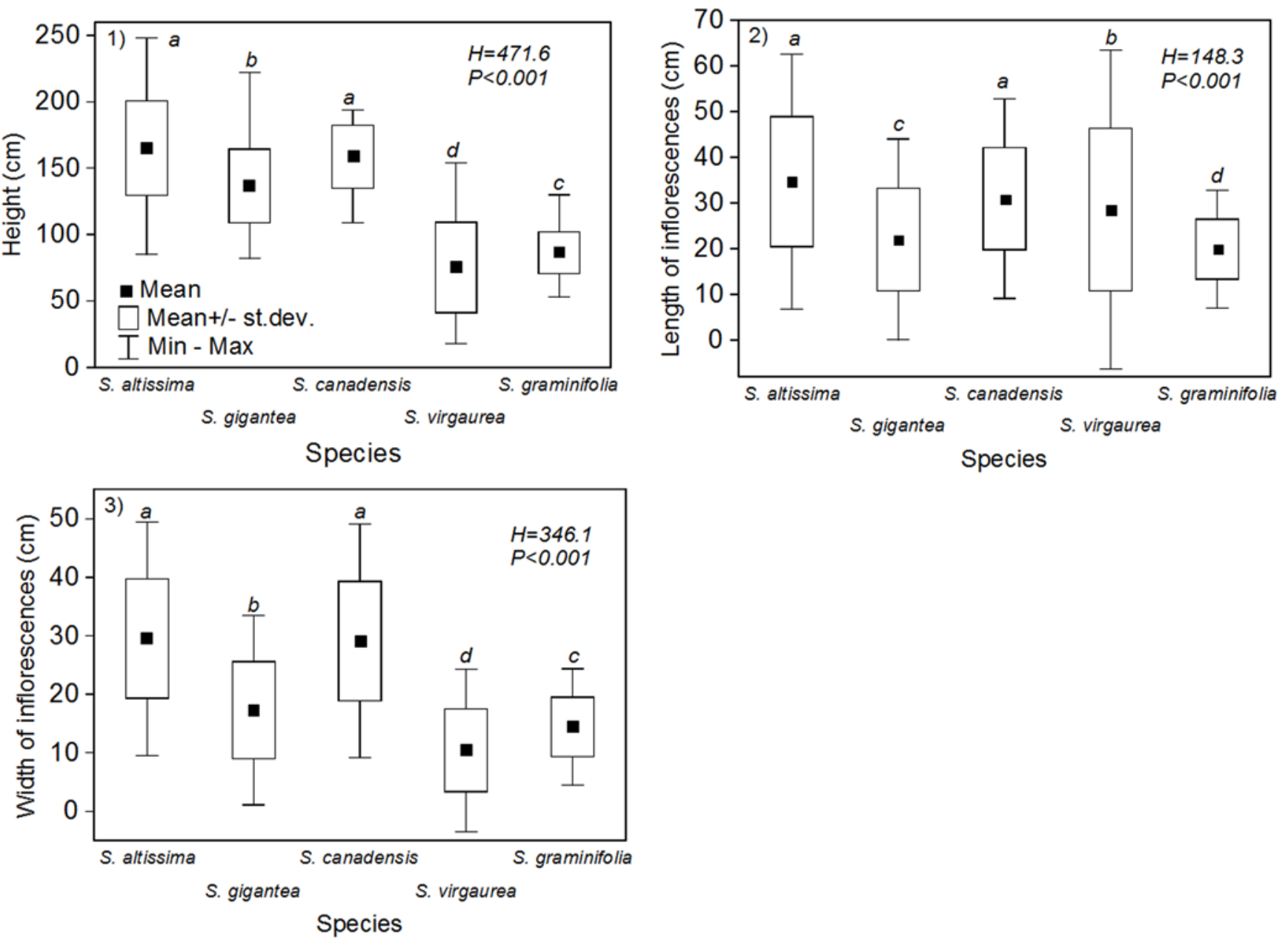

Fig. 7 Mean, standard deviation, minimum and maximum values of shoot height (1), inflorescence's length (2) and width (3) of the investigated Solidago taxa. The species marked by different small letters (a-d) differ significantly. Ten highest ramets of each species on every studied plot were measured (Solidago gigantea $N=430$, $S$. virgaurea $N=250$, S. altissima $N=310$, S. graminifolia $N=120, S$. canadensis $N=70$ ).

in other species, it can be an advantage for the establishment of new sites. [32,49]. Moreover, S. gigantea has long rhizomes, fragments of which can be easily transported by river currents, which allows for rapid infestation, whereas S. altissima, which occupies drier habitats, has compact and shorter rhizomes, which may constrain their colonization rate $[8,59]$. Therefore, the effect of inflorescence size could be changed by another, related to dispersal, traits.

Overshading by trees diminishes inflorescence size of Solidago virgaurea and S. gigantea. The comparison of this trait was possible, because these species occurred on both open and overshadowed habitats. As it was stated above, the size of inflorescence is a life-history trait $[47,60]$, considered as important in the colonization success. Therefore overshading could be discussed as a method of limiting the invasive Solidago species spreading.

Little is known about the ecology of S. graminifolia in Europe, as this species is restricted to a few widely separated sites. The life-history traits of S. graminifolia are different from those of the other two species, with a shorter stem and smaller inflorescences implying lower seed dispersal ability. One hypothesis concerning the issue of the limited range of S. graminifolia in Europe, is that this species is either lag phase or its spread is limited by factors other than climate [9]. The results of this study suggest, that soil properties do not limit its distribution. The recently observed rapid increase in its range, in south-western Poland (Z. Dajdok and B. Tokarska-Guzik personal communication 2010), as well as the variety of habitats occupied by S. graminifolia, suggest that this species could become a strong invader.

The only native Solidago species in Europe, S. virgaurea, is a weaker competitor than the American species, what has been confirmed by morphological traits (short plants with small inflorescences). The habitats of $S$. virgaurea do not overlap with alien species. In comparison with the exotic taxa, it could be considered as a stress-tolerant species, which allows it to grow in the shade in forests and nutrient poor mountain meadows.

As it was stated previously, the taxonomical status of Solidago species, currently occurring in Europe, is still discussed. Particularly, the taxonomical status of $S$. canadensis and $S$. altissima is unclear. Some morphological traits $[49,53,61]$ allow for distinguishing these two taxa, while on the other hand, the morphological variations reveal, that all the plants with pubescent stems in Europe belong to S. altissima [13]. The results of our study confirm the similarities between these two taxa, with respect to both morphological traits and soil preferences, but the differences of leaf hair and shapes are noticeable on field observations. Therefore, taxonomical status of the taxa requires more detailed study, in particular, analysis of chromosome numbers and indirect indicators of ploidy level. 


\section{Conclusions}

The environmental variables affect significantly the overall species composition, but we do not find niche differentiation among invasive Solidago species. Especially the habitat preferences of S. graminifolia, species with limited range, do not differ from another alien Solidago. The soil conditions (soil texture, $\mathrm{pH}$ and nutrient content) were not a good predictor of occurrence of particular Solidago taxa.

The soil properties influenced significantly Solidago species height and inflorescence size. The height of ramets is correlated with content of organic matter $(\mathrm{OM}), \mathrm{NO}_{3}, \mathrm{Ca}$ and $\mathrm{K}$ in case of Solidago gigantea and S. altissima, while the inflorescence size with $\mathrm{OM}, \mathrm{NO}_{3}, \mathrm{pH}, \mathrm{Ca}$ and $\mathrm{K}$ in case of S. gigantea, S. altissima and S. graminifolia.

Overshading by trees diminishes inflorescence size of Solidago virgaurea and S. gigantea, the species, which occurred more often on both open and overshadowed habitats.

The native species, $S$. virgaurea, occupies other environmental niche than the alien ones, e.g. shadow forests and mountain meadows. The morphological traits of the native goldenrod suggest its lower competitive ability, when compared to alien Solidago species.

Morphological traits (height of ramets and inflorescence size) of two similar species S. canadensis and S. altissima, do not differ significantly. The analysis of chromosome numbers and DNA content should be useful to establish the taxonomic status of these taxa.

\section{Acknowledgments}

The study was supported by grants of Wrocław University of Environmental and Life Sciences and NCN (N N305 401438).

\section{Authors' contributions}

The following declarations about authors' contributions to the research have been made: design of the study: MS; field research: MS, THS; analyzed the data and wrote the paper: MS, THS.

\section{References}

1. Semple JC, Cook RE. Flora of North America. Magnoliophyta. Asteridae. Asteraceae. New York NY: Oxford University Press; 2006. (vol 20 pt 7).

2. Weber E. Invasive plant species of the world: a reference guide to environmental weeds. New York NY: Oxford University Press; 2003.

3. McNeil J. Solidago L. In: Tutin TG, Heywood VH, Burges NA, Valentine DH, Walters SM, Webb DA, editors. Flora Europaea. Cambridge: Cambridge University Press; 1976. (vol 4).

4. Beaudry JR, Chabot DL. Studies on Solidago L. I. S. altissima L. and S. canadensis L. Contrib. Inst. Bot Univ Montr. Que. 1957;70:65-72.

5. Rostański K. Solidago L. In: Pawłowski B, Jasiewicz A, editors. Flora polska (Polish flora). Warsaw: Polish Scientific Publishers PWN; 1971.

6. Guzikowa M, Maycock PF. The invasion and expansion of three North American species of goldenrod [Solidago canadensis L. sensu lato, $S$. gigantea Ait. and S. graminifolia (L.) Salisb.] in Poland. Acta Soc Bot Pol. 1986;55:367-384.

7. Weber E. Morphological variation of the introduced perennial Solidago canadensis L. sensu lato (Asteraceae) in Europe. Bot J Linn Soc. 1997;123(3):197-210. http://dx.doi.org/10.1006/bojl.1996.0086
8. Weber E. The dynamics of plant invasions: a case study of three exotic goldenrod species (Solidago L.) in Europe. J Biogeogr. 1998;25(1):147-154. http://dx.doi.org/10.1046/j.1365-2699.1998.251119.x

9. Weber E. Current and potential ranges of three exotic goldenrods (Solidago) in Europe. Conserv Biol. 2001;15(1):122-128. http://dx.doi. org/10.1111/j.1523-1739.2001.99424.x

10. Dajdok Z, Nowak A. Solidago graminifolia (L.) Elliott in Poland - spreading and habitat preferences. In: Tokarska-Guzik B, Edwards K, editors. Plant invasions: human perception, ecological impacts and management. Leiden: Backhuys Publishers; 2008. p. 101-116.

11. Semple JC, Brammall RA, Chmielewski J. Chromosome numbers of goldenrods, Euthamia and Solidago (Compositae-Astereae). Can J Bot. 1981;59(7):1167-1173. http://dx.doi.org/10.1139/b81-159

12. Semple JC, Ringius GS, Leeder C, Morton G. Chromosome numbers of goldenrods, Euthamia and Solidago (Compositae: Astereae). II. Additional counts with comments on cytogeography. Brittonia. 1984;36(3):280-292. http://dx.doi.org/10.2307/2806528

13. Weber E. Biological flora of Central Europe: Solidago altissima L. Flora. 2000;195(2):123-134.

14. Małecka J. Studies on the genus Solidago L. I. Karyotype analysis of Solidago canadensis L. s.l. Acta Biol Cracov Bot. 1988;30:137-145.

15. Musiał K. Studies on the genus Solidago L. III Embriology of Solidago canadensis var. canadensis. Acta Biol Cracov Bot. 1989;31:73-84.

16. Weber E, Jakobs G. Biological flora of Central Europe: Solidago gigantea Aiton. Flora. 2005;200(2):109-118. http://dx.doi.org/10.1016/j. flora.2004.09.001

17. Schlaepfer DR, Edwards PJ, Semple JC, Billeter R. Cytogeography of Solidago gigantea (Asteraceae) and its invasive ploidy level. J Biogeogr. 2008;35(11):2119-2127. http://dx.doi. org/10.1111/j.1365-2699.2008.01937.x

18. Schlaepfer DR, Edwards PJ, Widmer A, Billeter R. Phylogeography of native ploidy levels and invasive tetraploids of Solidago gigantea. Mol Ecol. 2008;17(24):5245-5256. http://dx.doi. org/10.1111/j.1365-294X.2008.03980.x

19. Schlaepfer DR, Edwards PJ, Billeter R. Why only tetraploid Solidago gigantea (Asteraceae) became invasive: a common garden comparison of ploidy levels. Oecologia. 2010;163(3):661-673. http://dx.doi.org/10.1007/ s00442-010-1595-3

20. Stace CA. Plant taxonomy and biosystematics. London: Edward Arnold; 1989.

21. Wise MJ, Abrahamson WG. Genetic variation for susceptibility to storminduced stem breakage in Solidago altissima: the role of stem height and morphology. Acta Oecol. 2010;36(4):372-376. http://dx.doi.org/10.1016/j. actao.2010.03.003

22. Shea K. Community ecology theory as a framework for biological invasions. Trends Ecol Evol. 2002;17(4):170-176. http://dx.doi.org/10.1016/ S0169-5347(02)02495-3

23. Edwards KR, Adams MS, Kvet J. Differences between European native and American invasive populations of Lythrum salicaria. App Veg Sci. 1998;1(2):267-280. http://dx.doi.org/10.2307/1478957

24. Edwards KR, Adams MS, Kvet J. Invasion history and ecology of Lythrum salicaria in North America. In: Pyšek P, Prach K, Rejmánek M, Wade M, editors. Plant invasions: general aspects and special problems. Workshop held at Kostelec nad Černými lesy, Czech Republic, 16-19 September 1993. Amsterdam: SPB Academic Publishing; 1995. p. 161-180.

25. Sukopp H, Starfinger U. Reynoutria sachalinensis in Europe and in the Far East: a comparison of the species ecology in its native and adventive distribution range. In: Pyšek P, Prach K, Rejmánek M, Wade M, editors. Plant invasions: general aspects and special problems. Workshop held at Kostelec nad Černými lesy, Czech Republic, 16-19 September 1993. Amsterdam: SPB Academic Publishing; 1995. p. 151-159.

26. Starfinger U. On success in plant invasions. In: Starfinger U, Edwards K, Kowarik I, Williamson M, editors. Plant invasions: ecological mechanisms 
and human responses. Leiden: Backhuys Publishers; 1998. p. 33-42.

27. Mooney HA, Drake JA. The ecology of biological invasion of North America and Hawaii. New York NY: Springer; 1991.

28. Lodge DM. Biological invasions: lessons for ecology. Tree. 1993;8:133-137.

29. De Groot M, Kleijn D, Jogan N. Species groups occupying different trophic levels respond differently to the invasion of semi-natural vegetation by Solidago canadensis. Biol Conserv. 2007;136(4):612-617. http://dx.doi. org/10.1016/j.biocon.2007.01.005

30. Lonsdale WM. Global patterns of plant invasions and the concept of invasibility. Ecology. 1999;80(5):1522-1536. http://dx.doi. org/10.1890/0012-9658(1999)080[1522:GPOPIA]2.0.CO;2

31. Rejmánek M. Invisibility of plant communities. In: Drake JA, Mooney HA, diCastri F, Groves RH, Kruger J, Rejmánek M, et al., editors. Biological invasions: a global perspective. Willey; 1989. p. 369-387. (SCOPE report; vol 37).

32. Abrahamson WG, Dobley KB, Houseknecht HR, Pecone CA. Ecological divergence among five co-occurring species of old-field goldenrods. Plant Ecol. 2005;177(1):43-56. http://dx.doi.org/10.1007/s11258-005-2069-2

33. Krolikowska K, Dunajski A, Magnuszewski P, Sieczka M. Institutional and environmental issues in land reclamation systems maintenance. Env Sci Policy. 2009;12(8):1137-1143. http://dx.doi.org/10.1016/j.envsci.2009.09.001

34. Kutkowska B, Tańska-Hus B, Szybiga K, Łabędzki H. Przemiany społecznoekonomiczne w rolnictwie Dolnego Śląska. Aktualne problemy rolnictwa, gospodarki żywnościowej i ochrony środowiska. Wrocław: Wydawnictwo Uniwersytetu Przyrodniczego we Wrocławiu; 2006.

35. Chytrý M, Pyšek P, Wild J, Pino J, Maskell LC, Vilà M. European map of alien plant invasions based on the quantitative assessment across habitats. Divers Distrib. 2009;15(1):98-107. http://dx.doi. org/10.1111/j.1472-4642.2008.00515.x

36. Lambdon PW, Pyšek P, Basnou C, Hejda M, Arianoutsou M, Essl F, et al. Alien flora of Europe: species diversity, temporal trends, geographical patterns and research needs. Preslia. 2008;80(2):101-149.

37. Chytrý M, Pyšek P, Tichý L, Knollová I, Danihelka J. Invasions by alien plants in the Czech Republic: a quantitative assessment accross habitats. Preslia. 2005;77:339-354.

38. Tokarska-Guzik B. The expansion of some alien plant species (neophytes) in Poland. In: Child LE, Brock JH, Brundu G, Prach K, Pyšek P, Wade M, et al., editors. Plant invasions: ecological threats and management solutions. Leiden: Backhuys Publishers; 2003. p. 147-167.

39. Tokarska-Guzik B. The history of studies of invasive alien plants in Poland. In: Brundu G, Brock JH, Camarda L, Child LE, Wade M, editors. Plant invasions: species ecology and ecosystem management. Leiden: Blackhuys Publishers; 2001. p. 245-254.

40. Pyšek P. Alien and native species in Central European urban floras: a quantitative comparison. J Biogeogr. 1998;25(1):155-163. http://dx.doi. org/10.1046/j.1365-2699.1998.251177.x

41. Rothmaler W. Exkursionsflora von Deutschland. Bd. 3: Gefäßpflanzen: Atlasband. Munich: Spektrum Akademischer Verlag; 2007.

42. Rutkowski P. Klucz do oznaczania roślin naczyniowych Polski niżowej. Warsaw: Polish Scientific Publishers PWN; 2006.

43. Dzwonko Z. Przewodnik do badań fitosocjologicznych. Poznań: Sorus; 2007. (Vademecum Geobotanicum).

44. Mirek Z, Piękoś-Mirkowa H, Zając A, Zając M. Flowering plants and pteridophytes of Poland a checklist. In: Mirek Z, editor. Biodiversity of Poland. Cracow: W. Szafer Institute of Botany, Polish Academy of Sciences; 2002. (vol 1).

45. Kącki Z, Śliwiński M. The Polish Vegetation Database: structure, resources and development. Acta Soc Bot Pol. 2012;81(2):75-79. http://dx.doi. org/10.5586/asbp.2012.014

46. Lepš J, Šmilauer P. Multivariate analysis of ecological data using CANOCO. Cambridge: Cambridge University Press; 2003.

47. Jakobs G, Weber E, Edwards PJ. Introduced plants of the invasive Solidago gigantea (Asteraceae) are larger and grow denser than conspecifics in the native range. Divers Distrib. 2004;10(1):11-19. http://dx.doi. org/10.1111/j.1472-4642.2004.00052.x

48. Blossey B, Nötzold R. Evolution of increased competitive ability in invasive nonindigenous plants: a hypothesis. J Ecol. 1995;83(5):887-889. http:// dx.doi.org/10.2307/2261425

49. Schmid B, Puttick GM, Burgess KH, Bazzaz FA. Correlations between genet architecture and some life history features in three species of Solidago. Oecologia. 1988;75(3):459-464. http://dx.doi.org/10.1007/BF00376952

50. Weber E, Schmid B. Latitudinal population differentiation in two species of Solidago (Asteraceae) introduced into Europe. Am J Bot. 1998;85(8):1110. http://dx.doi.org/10.2307/2446344

51. Werner PA, Platt WJ. Ecological relationships of co-occurring goldenrods (Solidago: Compositae). Am Nat. 1976;110(976):959. http://dx.doi. org/10.1086/283120

52. Werner PA, Gross RS, Bradbury IK. The biology of Canadian weeds. 45. Solidago canadensis L. Can J Plant Sci. 1980;60(4):1393-1409. http://dx.doi. org/10.4141/cjps80-194

53. Melville MR, Morton JK. A biosystematic study of the Solidago canadensis (Compositae) complex. I. The Ontario populations. Can J Bot. 1982;60(6):976-997. http://dx.doi.org/10.1139/b82-123

54. Meyer AH, Schmid B. Experimental demography of the old-field perennial Solidago altissima: the dynamics of the shoot population. J Ecol. 1999;87(1):17-27. http://dx.doi.org/10.1046/j.1365-2745.1999.00315.x

55. Meyer G, Clare R, Weber E. An experimental test of the evolution of increased competitive ability hypothesis in goldenrod, Solidago gigantea. Oecologia. 2005;144(2):299-307. http://dx.doi.org/10.1007/ s00442-005-0046-z

56. Schmid B, Bazzaz FA, Weiner J. Size dependency of sexual reproduction and of clonal growth in two perennial plants. Can J Bot. 1995;73(11):1831-1837. http://dx.doi.org/10.1139/b95-194

57. Wade M. Predicting plant invasions: making a start. In: Brock JH, Wade M, Pyšek P, Green D, editors. Plant invasions: studies from North America and Europe. Leiden: Backhuys; 1997. p. 1-18.

58. Huang H, Guo S, Chen G. Reproductive biology in an invasive plant Solidago canadensis. Front Biol. 2007;2(2):196-204. http://dx.doi.org/10.1007/ s11515-007-0030-6

59. Ellenberg H. Vegetation Mitteleuropas mit den Alpen. Stuttgart: Ulmer; 1982.

60. Vuorisalo TO, Mutikainen PK, editors. Life history evolution in plants. Dordrecht: Kluwer Academic Publishers; 2001.

61. Szymura M, Wolski K. Leaf epidermis traits as tools to identify Solidago L. taxa in Poland. Acta Biol Cracov Bot. 2011;53(1):38-46. http://dx.doi. org/10.2478/v10182-011-0006-3 